\title{
ISTORIJA
}

\section{LIETUVOS TARYBOS ATSTOVAVIMAS SOVIETU RUSIJOJE 1918 METAIS}

Prof. DR. Sandra Grigaravičiūté

Šiauliu universiteto Socialiniu, humanitariniu mokslu ir menu fakulteto Istorijos ir filosofijos katedra Šiauliai University, Faculty of Social Sciences, Humanities and Art, Department of History and Philosophy

P. Višinskio g. 38, LT-76352 Šiauliai

El.paštas sandra.grigaraviciute@leu.lt

\section{Santrauka}

Straipsnyje analizuojama Lietuvos Tarybos vyriausiuju igaliotiniu Sovietu Rusijoje (Maskvoje ir Petrograde) paskyrimo, kompetencijos ir veiklos specifikos problematika. Tyrimas atskleidžia realiai egzistavusi Lietuvos Tarybos, Lietuvos ir Lietuvos piliečiu atstovavimo Sovietu Rusijos europineje dalyje (iki Uralo) mechanizma Vokietijos diplomatines ir konsulinès tarnybos sudetyje ir parodo pastangas perimti iš Vokietijos diplomatini ir konsulini Lietuvos atstovavima. Taip pat straipsnyje nagrinejjami Lietuvos atsiskyrimo nuo Rusijos ir Lietuvos piliečio radimosi klausimai.

Reikšminiai žodžiai: Lietuvos Taryba; atstovavimas; igaliotinis; Sovietų Rusija; Vokietija.

\section{Ivadas}

Lietuvos Taryba $\mathfrak{i}$ Lietuvos nepriklausomybès paskelbimą ir pripažinimą nukreiptą politiką užsienyje vykdè diplomatinemis 
priemonėmis - tiesiogiai ir netiesiogiai. Tiesiogiai su užsienio šalių politikais ir diplomatais bendravo Lietuvos Tarybos prezidiumo nariai, netiesiogiai - Lietuvos Tarybos igaliotiniai, vyriausieji igaliotiniai, Lietuvos Tarybos iggaliotos lietuvių institucijos užsienyje - lietuvių tautos tarybos (JAV, Šveicarijoje), vyriausiosios lietuvių tautos tarybos (Rusijos europineje dalyje, Urale ir Sibire, Ukrainoje, Gruzijoje, Šiaurès Kaukaze). Pirmąji igaliotinị Juozą Purickị Lietuvos Taryba paskyrè jau antrąją savo gyvavimo dieną ir igaliojo ji veikti Lietuvos Tarybos vardu ${ }^{1}$.

Lietuvių istoriografija iki šiol daugiausia dėmesio skyrė Lietuvos Tarybos ir jos igaliotinių diplomatinei veiklai neutraliose, Antantès šalyse ir Vokietijoje 1917 m. spalio - 1918 m. spalio mėnesiais ${ }^{2}$. Klausimas, ar Lietuvos Tarybos igaliotinių $1918 \mathrm{~m}$. buvo ir Rusijoje, kol kas nekeltas. Tyrëjų apsiribota Rusijos lietuvių ir jiems atstovaujančių

119180719 Lietuvos Tarybos prezidiumo igaliojimo raštas Juozui Purickiui. (Vollmacht). LMAVB RS, f. 255-1096, lap. 20.

2 Čepenas, P. Naujuju laiku Lietuvos istorija. T. 2. Fotografuotas leidimas. Vilnius: Lituanus, 1992, p. 34-83; Lietuvos istorija. T. 10, d. 1. Vilnius: Baltos lankos, [2013], p. 73-95; Eidintas, A. Views on Foreign Policy within the Lithuanian State Council 1917-1919. Studia Baltica Stockholmiensia. 1991, vol. 8, p. 373-380; Eidintas, A. Lithuania in European politics: the years of the first Republic, 19181940. Vilnius: Vaga, [2003], p. 11-31; Maksimaitis, M. Mažoji konstituanta: Lietuvos taryba atkuriant valstybinguma. Vilnius: Justitia, 2011. 432 p.; Laurinavičius, C̆.; Lopata R. Germany and Lithuania, 1917-1939. Lithuanian Foreign Policy Review. 2001, No 2 (8). Prieiga per internetą: http://www.lfpr.lt/uploads/File/2001-8/ Laurinavicius_Lopata.pdf; Lopata, R. Lietuvos valstybingumo raida 1914-1918 metais. Vilnius: Mintis. 1996. 223 p.; Motuzas, R. Lietuvos diplomatinis atstovavimas Švedijoje. Vilnius: Versus aureus, 2011, p. 52; Savickis, J. Skandinavija. Pirmasis nepriklausomos Lietuvos dešimtmetis 1918-1928. Fotografuotas leidimas. Kaunas: Šviesa, 1990, p. 59; Gaigalaite, A. Lietuvos Tarybos diplomatija. Mokslinès konferencijos ,Is Lietuvos diplomatijos istorijos “ medžiaga. Kaunas, 1994, p. 22-38; Grigaravičiūtè, S. History of Lithuanian diplomacy, 1918-1940: study guide for Lithuanian and Erasmus students. [Vilnius: Edukologija, 2013]. 88 p. (CD). Taip pat klasika tapusiuose darbuose: Žepkaité, R. Lietuva ir Didžiosios valstybès 1918 1939 m. Kaunas: Šviesa, 1986. 193 p.; Žepkaitè, R. Lietuva tarptautinès politikos labirintuose (1918-1922). Vilnius: Mintis, 1973. 193 p.; Žiugžda, R. Lietuva imperialistiniu valstybiu planuose, 1917-1940. Vilnius: Mokslas, 1983, 177 p. 
institucijų politinès veiklos analize Pirmojo pasaulinio karo metais ${ }^{3}$. Tačiau Lietuvos Tarybos ir Vyriausiosios lietuvių tarybos Rusijoje (toliau - VLTR) subordinaciniais ryšiais, kurie padètų išsiaiškinti Lietuvos Tarybos, o vèliau ir Lietuvos valstybès atstovavimo Rusijoje ištakas, - nesidomèta. Nuošalyje liko ir svarbus faktas, kad dauguma užsienio šalyse Pirmojo pasaulinio karo metais gyvenusių tremtinių ir pabègèlių lietuvių, kaip, beje, ir lietuviai Vokietijos okupuotose teritorijose, buvo Rusijos piliečiai.

Tyrimas atskleidžia realiai egzistavusị Lietuvos Tarybos, Lietuvos ir Lietuvos piliečių atstovavimo Sovietų Rusijos europinèje dalyje (iki Uralo) mechanizmą, priklausant Vokietijos diplomatinei ir konsulinei tarnybai, ir parodo pastangas perimti iš Vokietijos diplomatinị ir konsulinį Lietuvos atstovavimą, o negalint to padaryti bent jau pranešti Vokietijos karinei vadovybei Lietuvoje apie Lietuvos Tarybos igaliotinio ar vyriausiojo igaliotinio paskyrimą. Tyrimas taip pat svarbus dèl jame pateikiamų atsakymų ị esminius, su Lietuvos diplomatiniu ir konsuliniu atstovavimu užsienyje susijusius - Lietuvos atsiskyrimo nuo Rusijos ir Lietuvos piliečio radimosi - klausimus.

Tyrimo objektas - Lietuvos Tarybos vyriausiujuc igaliotinių Sovietų Rusijoje (Maskvoje ir Petrograde), subordinuotų Vokietijos diplomatinei ir konsulinei tarnybai, paskyrimo kontekstas, kompetencija, veiklos specifika. Tyrimo objektu tapo ir Lietuvos atsiskyrimo nuo Rusijos deklaracijos Lietuvoje ir užsienyje, Lietuvos piliečio radimosi kontekstas bei VLTR ryšiai su Lietuvos Taryba ir subordinacijos jai procesas. Tyrimo geografija apima europinę Sovietų Rusijos dalị iki Uralo, nes prasidejjus pilietiniam karui Urale ir Sibire kūrèsi ir veikè laikinosios vyriausybės, ryšys su ten gyvenančiais lietuviais nutrūko, ir

3 Balkelis, T. Moderniosios Lietuvos kūrimas. Vilnius: Lietuvos literatūros ir tautosakos institutas, 2012, p. 211-238; Čepènas, P. Naujuju laiku Lietuvos istorija. T. 2. Fotografuotas leidimas. Vilnius: Lituanus, 1992, p. 34-83; Yčas, M. Rusijos lietuvių pastangos kovose už Lietuvos nepriklausomybę. Pirmasis nepriklausomos Lietuvos dešimtmetis 1918-1928. Kaunas, 1990, p. 21-33. 
dèl to susiformavo atskiros lietuviams ir Lietuvos piliečiams atstovaujančios ir jų interesus ginančios institucijos ${ }^{4}$.

Tyrimas apima laikotarpi nuo 1918 m. gegužès 14 d. iki lapkričio 11 d., t. y. nuo Lietuvos Tarybos vyriausiojo igaliotinio Maskvoje „visai Rusijai“ - Česlovo Landsbergio paskyrimo iki Laikinosios Lietuvos Vyriausybès sudarymo, kai Lietuva, turèdama savo Vyriausybę, jau galejo skirti diplomatinị atstovą užsienyje. Laikotarpio pabaigos data yra santykinè, nes Vokietijai $1918 \mathrm{~m}$. lapkričio $5 \mathrm{~d}$. nutraukus diplomatinius santykius su Sovietų Rusija Vokietijos, o kartu ir Lietuvos piliečių atstovavimą Maskvoje perėmè Švedijos konsulas. Tyrimo ribos peržengtos aiškinantis Lietuvos atsiskyrimo nuo Rusijos deklaravimo procesą, Lietuvos piliečio radimąsi ir VLTR subordinacijos Lietuvos Tarybai procesus.

Lietuvos Tarybos atstovavimo Sovietų Rusijoje 1918 m. gegužès 14 d. - lapkričio 11 d. laikotarpiu, remiantis Lietuvos Tarybos vyriausiụjų igaliotinių Sovietų Rusijoje paskyrimo formuluočių ir jurisdikcijos kaita, išskirtini du etapai - pirmasis, nuo $1918 \mathrm{~m}$. gegužès $14 \mathrm{~d}$. iki rugpjūčio $21 \mathrm{~d}$. (nuo Lietuvos Tarybos vyriausiojo igaliotinio Maskvoje Č. Landsbergio paskyrimo iki Lietuvos Tarybos vyriausiojo krašto atstovo Maskvoje Tado Šulco paskyrimo) ir, antrasis, nuo $1918 \mathrm{~m}$. rugpjūčio $21 \mathrm{~d}$. iki lapkričio $11 \mathrm{~d}$. (nuo Lietuvos Tarybos vyriausiojo krašto atstovo Maskvoje T. Šulco paskyrimo iki Laikinosios Lietuvos Vyriausybès sudarymo). Pirmuoju etapu Lietuvos Tarybos atstovavimo centras ir rezidavimo vieta buvo Maskvoje, o antruoju - dviejuose miestuose: Maskvoje ir Petrograde, t. y. ten, kur veikẻ Vokietijos generaliniai konsulatai.

Lietuvos Tarybos atstovavimo Sovietų Rusijoje tyrimas atliktas pasitelkus publikuotus (spauda, atsiminimai, skelbti dokumentai) ir nepublikuotus šaltinius (Lietuvos centriniame valstybės archyve, Lietuvos mokslų akademijos Vrublevskių bibliotekos Rankraščių skyriuje).

4 Grigaravičiūtè, S. Lietuviu ir Lietuvos piliečiu atstovavimas Sibire 1918-1920 metais. - Straipsnio rankraštis ịteiktas leidybai 2017 m. liepos $18 \mathrm{~d}$. 
Isigilinti ị Lietuvos vyriausiųjų iggaliotinių Rusijoje (Maskvoje ir Petrograde) bei igaliotinių kituose Rusijos miestuose paskyrimo laiką, aplinkybes, kompetenciją, veiklos specifiką padejo Lietuvos centriniame valstybès archyve (LCVA) Lietuvių informacijos biuro fondo (f. 1486) 1 apraše, Lietuvos užsienio reikalų ministerijos fondo (f. 383) 18 apraše, Lietuvos Tarybos igaliotinio Maskvos atstovybès fonde (f. 1561), Lietuvos Valstybès Tarybos fondo (f. 1014) 1 apraše, Vokietijos užsienio reikalų ministerijos politinio archyvo (RZ 201), Lietuvos mokslų akademijos Rankraščių skyriaus (f. 70-1096, f. 255-1001, f. 255-1011, f. 70-286, f. 255-1029, f. 255-1024, f. 255-1052, f. 255-1068, f. 255-1063, f. 255-1079) fonduose esanti medžiaga. Vertingos informacijos suteikè dokumentai, publikuoti rinkinyje „Lietuvos Valstybès Tarybos protokolai“", $1918 \mathrm{~m}$. Centrinio lietuvių biuro Sibire (Tomske) leisti „Pranešimai“ (Nr. 1-2)6, laikraščiai „Vadas“ (Petrograde), „Darbo balsas“ (Vilniuje), „Vienybë“ (Kaune), „Laisve““ (Kaune). Išsiaiškinti Lietuvos Tarybos atstovavimo Sovietų Rusijoje ištakas padejo informacija, esanti LCVA Darbo ir socialinès apsaugos departamento fonde (f. 928), laikraščių "Lietuvių balsas“ (Voroneže), „Darbo balsas“ (Vilniuje), „Vienybë“ (Kaune), „Pranešimai“ (Tomske) 7 , „Komunistas“ (Voroneže), „Vadas“ (Petrograde) straipsniuose, ir Martyno Yčo atsiminimai ${ }^{8}$.

Issigilinti i tarptautinị Lietuvos vyriausiųjų igaliotinių Rusijoje (Maskvoje ir Petrograde) paskyrimo kontekstą padejo Winfriedo

5 Lietuvos Valstybès Tarybos protokolai, 1917-1918. Sudarė A. Eidintas, R. Lopata. Vilnius: Mokslas, 1991, p. 252.

6 Leidinys „Pranešimas“ yra įdètas filologès iš Sankt Peterburgo Alionos Pužychinos baigiamojo darbo prieduose. Prieiga per internetą: <http://www.genling.nw.ru/ baltist/diploms/2011Puz'ihina.pdf> (2017 07 01).

7 Lietuvos Valstybès Tarybos protokolai, 1917-1918. Sudarè A. Eidintas, R. Lopata. Vilnius: Mokslas, 1991, p. 252.

8 Yčas, M. Atsiminimai: Nepriklausomybès keliais. [T. 3]. 2-oji laida. [Chicago], 1991, p. 160. 
Baumgarto ${ }^{9}$ darbas, ị teisinius aspektus - Mindaugo Maksimaičio ${ }^{10}$, tarptautinės teisės aspektus - Aleksandro Jaščenkos ${ }^{11}$ darbai. Vertingu fragmentų apie lietuvių ir Lietuvos piliečių atstovavimą Rusijoje rasta Prano Čepèno veikale ${ }^{12}$ ir leidinyje apie Mykolą Sleževičių ${ }^{13}$, o lietuvių veikimą Švedijoje - Jono Šliūpo darbe ${ }^{14}$.

Tyrimas atliktas taikant analizės, lyginimo, aprašomąjį, šaltinių ir literatūros gretinimo metodus. Apdorojant pirminius šaltinius, ypač rusų, prancūzų ir vokiečių kalbomis, taikytas loginis-analitinis metodas (atlikta turinio ir informacijos prasminè analizè).

Tyrimo tikslas - ištirti Lietuvos Tarybos atstovavimą Sovietų Rusijoje nuo 1918 m. gegužès $14 \mathrm{~d}$. iki lapkričio $11 \mathrm{~d}$., atskleidžiant atstovavimo specifiką bendrame Lietuvos Tarybos atstovavimo užsienio šalyse kontekste. Siekiant tikslo: 1) analizuojamos Lietuvos Tarybos atstovavimo ištakos, atskleidžiama, kada ir kur deklaruotas atsiskyrimas nuo Rusijos, kada randasi Lietuvos pilietis, VLTR subordinavimo Lietuvos Tarybai procesas; 2) tiriamas Lietuvos Tarybos vyriausiojo igaliotinio Maskvoje Č. Landsbergio paskyrimo ir veiklos kontekstas, kompetencija, Rusijos lietuvių institucijų atstovų pagalba vykdant jam pavestas funkcijas; 3) nagrinejjami Lietuvos Tarybos atstovavimo Sovietų Rusijoje pokyčiai 1918 m. rugpjūčio 21 d. - lapkričio 11 d., atskleidžiama vyriausiųjų igaliotinių kompetencijos ir jurisdikcijos kaita.

9 Baumgart, W. Deutsche Ostpolitik 1918. Von Brest-Litowsk bis zum Ende des Ersten Weltkrieges. Wien u. München: Oldenbourg, 1966. S. 208-359. Prieiga per internetą: http://ubm.opus.hbz-nrw.de/volltexte/2010/2356/pdf/doc.pdf [Leidimas pakartotas 2010.]

${ }^{10}$ Maksimaitis, M. Mažoji konstituanta: Lietuvos taryba atkuriant valstybinguma. Vilnius: Justitia, 2011, p. 113-114.

11 Jaščenka, A. Tarptautinès teisès kursas. Kaunas, 1931, t. 1, p. 237, 238.

12 Čepenas, P. Naujuju laiku Lietuvos istorija. T. 2. Fotografuotas leidimas. Vilnius: Lituanus, 1992, p. 34-83.

${ }_{13}$ Mykolas Sleževičius: [straipsnių rinkinys]. Chicago: Terra, 1954, p. 74.

14 Szlupas, J. Essey on the past, present and future of Lithuania. Stockholm, 1918, p. $40-43$. 


\section{Lietuvos Tarybos atstovavimo Sovietų Rusijoje ištakos}

Aiškinantis Lietuvos Tarybos atstovavimo Sovietų Rusijoje ištakas esminiai yra trys klausimai: pirmas, kada viešai padaryti Lietuvos Tarybos ar jos igaliotų atstovų užsienyje pareiškimai apie Lietuvos atsiskyrimą nuo Rusijos, antras, kada randasi Lietuvos pilietis ir, trečias, ar Vyriausiąją lietuvių tarybą Rusijoje galime laikyti Lietuvos Tarybos atstove Rusijoje, t. y. ar ji pripažino Lietuvos Tarybą ir buvo jai subordinuota.

\subsection{Kada ir kur deklaruotas Lietuvos atsiskyrimas nuo Rusijos}

Lietuvių istoriografijoje yra gerai žinomi trys Lietuvos atsiskyrimo nuo Rusijos paskelbimai, - du lietuvių pareiškimai užsienyje - Lozanoje ir Stokholme ir vienas - Vilniuje. Datos - 1917 m. gruodžio 25 d., 1918 m. sausio 6 d. ir sausio 26 diena. 1917 m. gruodžio 25 d. deklaracija, kurioje skelbiamas atsiskyrimas nuo Rusijos, pateikta keliuose šaltiniuose. Vienas jų yra publikuotas 1918 m. leidinyje „Pro Lithuania“ (nr. 3, p. 61) ${ }^{15}$, o kitas paminètas kariaujančioms ir neutralių šalių atstovams $1918 \mathrm{~m}$. gegužès $16 \mathrm{~d}$. Lietuvių tautos tarybos Lozanoje rašytame rašte ${ }^{16}$. Lietuvių spaudoje sutrumpintas šios deklaracijos teksto variantas išspausdintas 1918 m. sausio 26 dieną Konkreti deklaracijos data „Darbo balse“ nebuvo paminèta. Pasakyta, kad tai yra „plačiai vokiečių spaudoje paskleistas“ Lietuvių informacijos biuro Lozanoje pareiškimas. Jo 3-ioje ir 4-oje dalyje teigiama: „Tautos Taryba, kaipo tikra vyriausiųjų tèvynės reikalų gynèja pareiškia $\langle\ldots>$ kad lietuvių tauta nuo šios dienos pertraukia visus ryšius su Rusija ir, remdamosi tautų

${ }^{15}$ Notification de l'indépendence de la Lituanie aux Etats belligerants et neutres. Pro Lithuania. 1918, No 3, p. 61-63; Politisches Archiv des Auswartiges Amts (toliau PAAA) PAAA_RZ201_021717_205-207.

1619180516 Lietuvių Tautos Tarybos raštas kariaujančioms ir neutralių šalių atstovams. LCVA, f. 1486, ap. 1, b. 1, lap. 22-23. 
apsisprendimo teise, turi teisès ir priedermès imti ị savo rankas tautos likimą ir reikalauti jai nepriklausomybès per kitas valstybes. ${ }^{\text {"17 }}$

Konkreti Lietuvos atsiskyrimo nuo Rusijos pareiškimo data nèra nurodyta ir išlikusiame Lietuvių tautos tarybos Lozanoje rašto Woodrow Wilsonui, Deividui Lloidui Georgui, Vittorio Emanuele Orlando ir Georges Clemenceau projekte. Virš mašinèle spausdinto teksto ranka pieštuku prirašyta $1918 \mathrm{~m}$. sausis (Janvier 1918) ${ }^{18}$. Jame yra analogiška paskelbtajai (spaudoje) formuluotė apie atsiskyrimą nuo Rusijos („Que le peuple lituanien se considere d'ores et déjá degage de tout liens envers l'etate russe"), tačiau po deklaracijos teksto yra pakartotinai pabrěžta, kad „atsiskiriama nuo Rusijos ir sukuriama nepriklausoma valstybë“ („Cett déclaration qui constitue, le programme national approuvé par tout notre peuple démontre sa volonté inébranlable de se séparerà tout jamais de la Russie afin dese constituer en unn Etate indépendant") ir prašoma pripažinti Lietuvos nepriklausomybę ${ }^{19}$.

Šveicarijoje oficialius Lietuvos Tarybos igaliojimus, išduotus dar vykstant Lietuvių konferencijai Vilniuje 1917 m. rugsèjo 22 d., turëjo Juozas Purickis ${ }^{20}$. Igaliojime buvo parašyta, kad jis yra „igaliotas atstovauti Lietuvos interesus užsienyje, kalbèti ir derètis Lietuvos Tarybos vardu bei sudaryti sutartis (prieš tai patvirtinus Tarybai)“ („dass er hier durch ermächtigt wird, die Interessen Litauens im Auslande zu vertreten,

$17,3)$ dabartinị laiką didžioji Lietuvos dalis užimta yra vokiečių kariuomenès ir rusai nieko neịstengia dèl jos pagelbèti, nors lietuviai tebepildo savo dėlei jos pareigas. Dèl to visa Tautos Taryba, kaipo tikra vyriausiujų tėvynės reikalų gynejja pareiškia: 4) kad lietuvių tauta nuo šios dienos pertraukia visus ryšius su Rusija ir, remdamosi tautų apsisprendimo teise, turi teisès ir priedermès imti ị savo rankas tautos likimą ir reikalauti jai nepriklausomybès per kitas valstybes.“ Žr. Visuomenès atbalsiai. Darbo balsas. 1918, sausio 26 (Nr. 6), p. 11.

181918 sausis. Lietuvių Tautos Tarybos Lozanoje rašto projektas W. Wilsonui, L. Georgui, Orlando ir Clemaceau. LCVA, f. 1486, ap. 1, b. 1, lap. 9-11.

191918 sausis. Lietuvių Tautos Tarybos Lozanoje rašto projektas W. Wilsonui, L. Georgui, Orlando ir Clemaceau. LCVA, f. 1486, ap. 1, b. 1, lap. 9-11.

${ }^{20} 19180719$ Lietuvos Tarybos prezidiumo igaliojimo raštas Juozui Purickiui. (Vollmacht). LMAVB RS, f. 255-1096, lap. 20. 
im Namen der Taryba zu sprechen, zu verhandeln, sowie Verträge im Namen der Taryba, vorbehaltlich ihrer Bestätigung durch die Taryba, abzuschliessen") ${ }^{21}$. Visuose Lietuvių tautos tarybos raštuose tiek kariaujančioms, tiek ir neutralioms šalims buvo pabréžiama, kad ji (Lietuvių tautos taryba) yra Lietuvos Tarybos (Vilniuje) igaliota jai atstovauti ${ }^{22}$.

Antrasis pareiškimas padarytas $1918 \mathrm{~m}$. sausio $6 \mathrm{~d}$. trečiojoje lietuvių konferencijoje Stokholme ${ }^{23}$. Joje buvo pareikšta apie Lietuvos nepriklausomybę ir atsiskyrimą nuo Rusijos 1 straipsnio a) dalyje: „paskelbdama lietuvių tautą jos etnografinèse sienose esant laisvą ir nepriklausomą nuo Rusijos"24. Šioje konferencijoje dalyvavo oficialus Lietuvos Tarybos igaliotinis Jurgis Šaulys. Jo misijos tikslas buvo paskelbti Lietuvos nepriklausomybę Stokholme ${ }^{25}$. Trečiosios lietuvių konferencijos Stokholme nutarimai buvo paskelbti skandinavų spaudoje $^{26}$, tačiau trumai jų turinys buvo referuotas ir Vilniaus lietuvių periodikoje $\mathrm{e}^{27}$.

Lietuvos Tarybos Vilniuje atsiskyrimas nuo Rusijos buvo pareikštas 1918 m. sausio 26 dieną. Lietuvos Taryba nutarè kreiptis į Rusijos vyriausybę šiuo pareiškimu: „Lietuvos Taryba, kuri krašto lietuvių ir užsienio lietuvių yra pripažinta vienintele igaliota lietuvių tautos atstovybe, remdamos pripažintąja tautų apsisprendimo teise ir lietuvių

21 Ten pat.

22 „L'organe de ses relations extérieures marchant étroitement d’accord avec la Taryba". Žr. [Be datos] Notice Concernant la Restauration de l'Etat Lituanien. LCVA, f. 1486, ap. 1, b. 1, lap. 25-31; Lietuvių konferencijos Berne rezoliucijos. LCVA, f. 675, ap. 1, b. 45, p. 21.

${ }^{23}$ Grigaravičiūtè, S. Skandinavija Lietuvos diplomatijoje 1918-1940 metais: monografija. Vilnius: Saulabrolis, 2002, p. 40-44.

${ }^{24}$ Ten pat, p. 244. Tas pats anglų kalba, žr. Szlupas J. Essey on the past, present and future of Lithuania. Stockholm, 1918, p. 40-43.

${ }_{25}$ Grigaravičiūtè, S. Skandinavija Lietuvos diplomatijoje 1918-1940 metais: monografija. Vilnius: Saulabrolis, 2002, p. 40-44.

${ }^{26}$ Mažeika, V. Danijos santykiai su Lietuva 1918-1940 m. Vilnius: LII leidykla, 2002, p. 24; Grigaravičiūtè, S. Skandinavija Lietuvos diplomatijoje 1918-1940 metais. Vilnius: Saulabrolis, 2002, p. 40-44.

27 Visuomenès atbalsiai. Darbo balsas. 1918, sausio 26 (Nr. 6), p. 11. 
Vilniaus konferencijos nutarimu rugsejjo mèn. 17-23 d. 1917 metais, skelbia atstatanti nepriklausomą Lietuvos valstybę su sostine Vilniuje ir tą valstybę atskirianti nuo visų valstybinių ryšių, kurie yra buvę su kitomis tautomis. Lietuvos Taryba, pranešdama apie šitai Rusijos vyriausybei, šiuomi pareiškia, kad nuo šios dienos Lietuva yra išèjusi iš Rusijos valstybès sąstato ir laiko save nepriklausoma valstybe. “28

\subsection{Kada randasi Lietuvos pilietis}

Pirmojo pasaulinio karo metais Vokietijai okupavus lietuvių gyvenamas teritorijas, jie buvo Rusijos imperijos piliečiai. Tą puikiai iliustruoja Pranciškaus Karevičiaus pareiškimas Vokietijos karinei vadovybei Kaune 1916 metais. P. Karevičius, grịžęs iš Rusijos ị okupuotą Lietuvą, Vokietijos karinei vadovybei pasakè, kad „Lietuva vokiečių yra okupuota, bet ji nèra prie Vokietijos prijungta. Mes ir toliau pasiliekame Rusijos piliečiai. ${ }^{29} 1918$ m. kovo 3 d. pasirašius Brest Litovsko sutartị lietuviai tiek Vokietijos okupuotoje dalyje, tiek tremtiniai ir belaisviai Rusijoje ir kitose užsienio šalyse laikinai tapo Vokietijos pavaldiniais. Brest Litovsko sutartimi „Lietuva perejjo laikinam Vokietijos suverenitetui““30. Vokietijos kaizeris Vilhelmas II $1918 \mathrm{~m}$. kovo $23 \mathrm{~d}$. pripažino Lietuvą "laisva nepriklausoma monarchiniais pagrindais sutvarkyta valstybe“, to pripažinimo pagrindu laikydamas Lietuvos Tarybos $1917 \mathrm{~m}$. gruodžio $11 \mathrm{~d}$. nutarimą ${ }^{31}$. $1918 \mathrm{~m}$. kovo 23 diena lietuvių tautinių tarybų Rusijos imperijos teritorijoje susikūrusiose valstybėse laikyta atskaitos data Lietuvos piliečių interesams ginti. Lietuvių vyriausiosios tarybos Ukrainoje išduodamuose liudijimuose buvo parašyta: „[S]ulig Lietuvos Tarybos paskelbtos 22-23 kovo mèn. 1918 m.

${ }^{28} 19180127$ ištrauka iš Lietuvos Tarybos protokolo. LCVA, f. 383, ap. 18, b. 297, lap. 34.

${ }^{29}$ Yčas, M. Atsiminimai: Nepriklausomybès keliais. [T. 3]. 2-oji laida. [Chicago], 1991, p. 160.

${ }^{30}$ Maksimaitis, M. Mažoji konstituanta: Lietuvos taryba atkuriant valstybinguma. Vilnius: Justitia, 2011, p. 113.

${ }^{31}$ Ten pat, p. 114. 
Lietuvos nepriklausomybès ir visiems priverstinos tarptautinès teisès šiojo Lietuvos piliečio asmuo, butas ir turtas yra neliečiami; jo suèmimas, kratos ir turto rekvizicijos tegalimos Lietuvių Tarybos igaliotiniui dalyvaujant." ${ }^{\text {32 }}$

Neabejojame, kad ne vieną tyrëją ar (ir) skaitytoją suglumins frazė „Lietuvos Tarybos paskelbtos 22-23 kovo mèn. 1918 m. Lietuvos nepriklausomybès“, tiksliau, nepriklausomybès paskelbimo datos. Kodèl ne Vasario 16 diena? Manytume, kad šios datos pasirinktos neatsitiktinai. $1918 \mathrm{~m}$. vasario $22 \mathrm{~d}$. Vokietijos Reichstage buvo ratifikuota Brest Litovske pasirašyta sutartis ${ }^{33}$. Todèl pirmoji data yra $1918 \mathrm{~m}$. kovo 22 diena. Berlyne viešejusi Lietuvos Tarybos delegacija, kuriai Vokietijos kaizeris deklaravo Lietuvos de jure pripažinimą, buvo igaliota ir „1918 m. kovo 23 d. notifikavo Lietuvos nepriklausomybę pagal Vasario 16-osios nutarimo formulę “34. Taigi antroji data žymi Vasario 16-osios akto notifikaciją Vokietijai. Vokietijos kaizeris suteikè Lietuvai pripažinimą taip pat tą pačią dieną.

Sibiro lietuviai laikèsi nuostatos, kad Lietuvai $1918 \mathrm{~m}$. vasario 16 d. paskelbus, o Vokietijos kaizeriui pripažinus Lietuvos nepriklausomybę (apie tai Sibiro lietuvių spaudoje buvo pranešta $1918 \mathrm{~m}$. liepos $15 \mathrm{~d} .{ }^{35}$ ) „kiekvienas lietuvis turi teisę vadinti save Lietuvos piliečiu“"36. Vilniuje leidžiamoje lietuvių spaudoje $1918 \mathrm{~m}$. gegužès

3219180709 Klemensui Matusevičiui išduotas Lietuvių vyriausios tarybos Ukrainoje liudijimas. LCVA, f. 928, ap. 28, b. 3, lap. 246a.

${ }_{33}$ Čepènas, P. Naujuju laiku Lietuvos istorija. T. 2... p. 245.

${ }^{34}$ Maksimaitis, M. Mažoji konstituanta: Lietuvos taryba atkuriant valstybinguma. Vilnius: Justitia, 2011, p. 114; 19180323 J. Šaulio, J. Staugaičio, J. Vileišio pasirašytas raštas Vokietijos vyriausybei (An die Keiserlich Deutsche Regierung). PAAA_RZ201_021717_023.

${ }^{35}$ Apie Lietuvos nepriklausomybę. Centralis Lietuviu Biuras Sibire. Pranešimas No 2. Tomskas, 191807 15, p. 4.

${ }^{36}$ Visiems lietuviams, besiteiraujantiems apie Lietuvos nepriklausomybę, buvo pranešama apie Vokietijos kaizerio manifestą, kuris Lietuvos Tarybos prezidiumui buvo ịteiktas $1918 \mathrm{~m}$. gegužès $4 \mathrm{~d}$. Žr. Apie Lietuvos nepriklausomybę, Centralis Lietuviu Biuras Sibire. Pranešimas No 2. Tomskas, 191807 15, p. 4. 
24 d. buvo paskelbta, kad „Kurliandija ir Lietuva pripažintos nepriklausomomis valstybèmis“, todèl „vyriausias vadas rytuose ịsakè ateityje visuose valdžios raštuose (pasuose), išduodamuose Kurliandijos ir Lietuvos piliečiams, vadinti juos nebe Rusijos, bet Kurliandijos arba Lietuvos pavaldiniais"37. Taigi, atskaitos data yra Vokietijos kaizerio suteiktas pripažinimas, t. y. 1918 m. kovo 23 diena.

\subsection{Ar Vyriausioji lietuvių taryba Rusijoje buvo subordinuota Lietuvos Tarybai}

Lietuvių atstovavimo Rusijoje èmèsi 1917 m. gruodžio $1 \mathrm{~d}$. įsteigta Vyriausioji lietuvių taryba Rusijoje. Ji atstovavo lietuvių interesams Rusijos įstaigose, tarp užsienio šalių atstovybių, siuntė atstovą i taikos derybas Brest Litovske, išdavė lietuviams pasus ${ }^{38}$ ir liudijimus, rinko mokesčius savo veiklai vykdyti ${ }^{39}$. Ši diplomatinès formos veikla laikytina tarpiniu atstovavimu, tarp paprastojo ir diplomatinio atstovavimo ${ }^{40}$. Tačiau šiame procese esminis klausimas, ar buvo VLTR subordinacinis ryšys su Lietuvos Taryba Vilniuje, kuri buvo vienintelè igaliota „atstovauti lietuvių tautą ir jos politinę kryptị". Paprasčiau tariant, ar VLTR pripažino Lietuvos Tarybą kaip aukščiausią tautos instituciją ir ar buvo jai subordinuota?

${ }^{37}$ Rygos gubernijos gyventojai laikomi Lifliandijos pavaldiniais. Žr. Lietuvos pavaldiniai. Vienybè. 1918, gegužès 24 (Nr. 18), p. 277.

${ }^{38}$ Draugelis, E. Lietuviškieji pasai. Lietuviu balsas. 1918, sausio 1 (Nr. 1), p. 2. „Išduotieji Tarybos pasai turès didelę psichologinę vertę: jie ugdys žmonèse mintị apie lietuvių valdžios esmę. Taip pat ir pilietinę reikšmę turès: tie pasai auklės žmonėse valstybini susipratimą. "Buvo išrinkta LVTR pasų spausdinimo komisija. Pasus rengè 3 kalbom (lietuvių, rusų, vokiečių). Spaudoje buvo aprašytas pasų ịsigijimo iš LVTR būdas: parsisiųsdins vietinès lietuvių tarybos iš LVTR už pinigus. Jei mieste nèra tarybos, tai galèjo padaryti draugija. Lietuviu draugijos CK perdavè liudijimų išdavimą LVTR. Liudijimas kainavo $3 \mathrm{rb}$. Pinigai buvo renkami į Tautos fondą. Dèl „lietuviškų pasų“. LVTR pranešimas. Lietuvių balsas. 1918, sausio 12 (Nr. 3), p. 2.

${ }^{39}$ Trijų partijų suvažiavimas Voroneže. Lietuviu balsas. 1917, lapkričio 30 (Nr. 65), p. 2-3.

40 Jaščenka, A. Tarptautinès teisès kursas. Kaunas, 1931, t. 1, p. 237, 238. 
Išrinkus VLTR nebuvo paskelbta, kad ji laiko Lietuvos Tarybą Vilniuje vienintele igaliota atstovauti „lietuvių tautą ir jos politinę kryptį“. Knygos apie M. Sleževičių sudarytojai teigia, kad „LVTR, 1918 m. vasario $16 \mathrm{~d}$. Lietuvos Tarybai Vilniuje paskelbus Lietuvos nepriklausomybės aktą, pasidarè savotiška lietuvių atstovybe“" ${ }^{\text {“1 }}$. Tačiau oficialaus Lietuvos Tarybos igaliojimo jai atstovauti LVTR neturejo.

Taigi esminis klausimas, ar VLTR buvo subordinuota Lietuvos Tarybai Vilniuje ir, jei taip, - kada. Jau pirmuose posėdžiuose 1917 m. gruodžio 14-18 d. (n. k.) LVTR nusprendè siųsti „igaliotą žmogų ị Lietuvą, kad, tikrai aiškiai viską susižinojus, planingai ir tvarkingai grąžintum namo tremtinius" ${ }^{\text {"42 }} .1918 \mathrm{~m}$. sausio 2 d. (n. k.) LVTR Petrogrado prezidiumas išrinko komisiją, kuri susisiektų su Vokietijos atstovais Petrograde ir paprašytų leidimo LVTR atstovams „susivažiuoti“ su Lietuvos Tarybos nariais ${ }^{43}$. Tikslas - išsiaiškinti grąžinimo tvarką, būdus, pasus. Po šio nutarimo LVTR nekèlè tokio klausimo iki 1918 m. vasario 3 d. (n. k.). Klausimą vèl iškèlè Eliziejus Draugelis, siūlydamas kreiptis ị Vokietijos pasiuntinị Wilhelmą von Mirbachą Petrograde ${ }^{44}$.

Iš publikacijų Rusijos lietuvių spaudoje matyti, kad VLTR palaikè ryšius su Lietuvos Taryba Vilniuje ir su ja derino savo veikimą („Voldemaras nuvykęs Brestan žadejjo kuo veikiausiai susižinoti su didžiosios Lietuvos Taryba ir pasistengti, kad atstovas iš Vilniaus (nuo

${ }^{41}$ Mykolas Sleževičius: [straipsnių rinkinys]. Chicago: Terra, 1954, p. 74.

42 Lietuvių Vyriausios Tarybos posėdžiai. Lietuvių balsas. 1917, gruodžio 7 (Nr. 66), p. $1-2$.

43 Vyriausioji Lietuvių Taryba tremtinių grąžinimo reikalu. Lietuviu balsas. 1918, vasario 14 (Nr. 6), p. 1.

44 Ten pat. W. Mirbachas po Brest Litovsko sutarties pasirašymo dirbo Petrograde civilių ir karo belaisvių apsikeitimo darbe. Baumgart, W. Deutsche Ostpolitik 1918. Von Brest-Litowsk bis zum Ende des Ersten Weltkrieges. Wien u. München: Oldenbourg, 1966. S. 209. Prieiga per internetą: http://ubm.opus.hbz-nrw.de/ volltexte/2010/2356/pdf/doc.pdf [Leidimas pakartotas 2010.] 
Tarybos) dalyvautų Brestos tarybose ${ }^{* 45}$ ). Tai rodo pastangas sulaukti Brest Litovske atstovo iš Lietuvos Tarybos. Savo ruožtu matyti, kad Lietuvos Taryba bande išsiųsti ị Ukrainą savo igaliotinį, kuris susitiktų su VLTR deleguotais asmenimis Ukrainoje. $1918 \mathrm{~m}$. vasario $20 \mathrm{~d}$. Lietuvos Tarybos pirmininkas kreipèsi ị Vokietijos karinès vadovybès viršininką Lietuvoje bandydamas gauti leidimą vykti ị Ukrainą Lietuvos Tarybos igaliotiniui organizuoti tremtinių ir pabėgèlių grąžinimą ${ }^{46}$. Tačiau nesèkmingai.

Praèjus kelioms savaitėms po Brest Litovsko sutarties pasirašymo, ì Vilnių atvyko ir Lietuvos Tarybos posėdžiuose $1918 \mathrm{~m}$. kovo $21 \mathrm{~d}$. dalyvavo VLTR atstovai - Liudas Noreika, kpt. Jonas Variakojis, kpt. Kazys Škirpa; jie informavo apie padèti Sovietų Rusijoje ${ }^{47}$. Martynas Yčas savo atsiminimuose mini $1918 \mathrm{~m}$. pavasarị ì Vilnių LVTR siųstą delegaciją - L. Noreiką, kpt. Joną Variakojị, kpt. K. Škirpą, ir vadina juos „pirmais delegatais ì Lietuvos Tarybą Vilniun praskinti keliui mūsų tremtiniams grižti iš namų nevalios" ${ }^{\text {"48. }}$.

Iš Lietuvos Tarybos ir VLTR susirašinèjimo matyti, kad Lietuvos Taryba Vilniuje rūpinosi bolševikų Rusijoje suimtais VLTR nariais, prašė jiems Vokietijos konsulinès globos. Lietuvos Taryba Vilniuje gavo 1918 m. kovo 23 d. Lietuvių tautos tarybos Minske laišką, kuriame pranešta, kad ị Minską atvykęs VLTR narys Vytautas Petrulis informavo apie VLTR narių suėmimą ir kratas būstinèje Voroneže. V. Petruliui pavyko iš Voronežo išvykti ị Maskvą, o iš jos į Gomelį. Iš Gomelio jis pasiekè Minską ir planavo vykti ị Vilnių. Suimti buvo 10 VLTR narių (Pranas Mašiotas, Jonas Jablonskis, Martynas Yčas, Mykolas Sleževičius, Julijonas Jasienskis, Zigmas Žemaitis, Pranas Penkauskas, Juozas

45 „Tèvynès gelbètojų“ žygiai. Komunistas. 1918, Nr. 3, p. 14-16.

4619180220 Lietuvos Tarybos pirmininko raštas Vokietijos karo vadovybei Lietuvoje. LMAVB RS, f. 255-1001, lap. 4.

${ }^{47}$ Lietuvos Valstybès Tarybos protokolai, 1917-1918. Sudare A. Eidintas, R. Lopata. Vilnius: Mokslas, 1991, p. 226.

48 Yčas, M. Atsiminimai: Nepriklausomybès keliais [T. 3]. 2-oji laida. [Chicago], 1991, p. 136. 
Vailokaitis, Liudas Daukša, Adomas Varnas). Lietuvių tautos taryba Minske prašė Lietuvos Tarybos Vilniuje imtis priemonių išlaisvinti suimtuosius ${ }^{49}$.

V. Petrulis ị Vilnių atvyko $1918 \mathrm{~m}$. kovo 29 dieną. Lietuvos Taryba 1918 m. balandžio 2 d. kreipèsi ị Vokietijos karinę vadovybę Lietuvoje prašydama padèti. Laiške nurodyta, kad po taikos sutarties pasirašymo pabėgèliai nori grịžti namo iš Rusijos ir VLTR grịžtantiems išduodavo pažymèjimus (Ausweis) trimis kalbomis. Rusijos vyriausybė tų pažymejjimų nepripažino ir pabėgèliai negalèjo grị̌ti namo, buvo priversti stoti ị Raudonąją armiją. Kadangi Vokietija pažadejjo nepriklausomai Lietuvos valstybei pagalbą ir apsaugą ${ }^{50}$, Lietuvos Taryba, kaip „Lietuvos valstybès atstovybe்“, prašè Vokietijos vyriausybès pasirūpinti lietuviais Sovietų Rusijoje ir apsaugoti juos nuo bolševikų persekiojimo. Lietuvos Taryba prašė Vokietijos vyriausybès iš Sovietų Rusijos pareikalauti: 1) paleisti suimtus VLTR narius; 2) leisti VLTR organizuoti lietuvių pabègèlių grịžimą ị Lietuvą; 3) grąžinti ị Lietuvą kultūros ir švietimo įstaigas kartu su jose besimokančiais moksleiviais ir dirbančiais mokytojais Rusijos vyriausybės sąskaita ${ }^{51} .1918 \mathrm{~m}$. balandžio $2 \mathrm{~d}$. Vokietijos karinè vadovybė Lietuvoje informavo Lietuvos Tarybos prezidentą A. Smetoną, kad Vokietijos vyriausybė kreipèsi ị Rusijos vadovybę, prašydama suimtus VLTR narius išleisti ị laisvę ${ }^{52}$.

1918 m. balandžio pradžioje Minsko lietuviai buvo subordinuoti Lietuvos Tarybai Vilniuje. 1918 m. balandžio 9 d. kun. Vladas Mironas dalyvavo Minsko lietuvių tarybos posedyje, jis informavo apie Lietuvos

${ }_{49} 19180323$ S. Mičiulio ir E. Misevičiaus laiškas (vok. k.) Lietuvos Tarybai. LMAVB RS, f. 255-1011, lap. 1.

${ }^{50}$ „Kurland und Litauen stehen unter deutschem Schutz <...>“. Žr. 19180329 Vokietijos karininko Oberoste telegrama Vokietijos URM ir atsakymas i ją. PAAA_RZ201_021717_126-127.

${ }^{51} 19180402$ Lietuvos Tarybos raštas Vokietijos karinei vadovybei Lietuvoje. MAVB RS, f. 255-1011, lap. 3-3 apv.

${ }^{52} 19180402$ Vokietijos karinès vadovybès Lietuvoje raštas Lietuvos Tarybos prezidentui A. Smetonai. MAVB RS, f. 255-1096, lap. 1. 
Tarybos darbus ir gavo „pritarimą ir paramą“ Lietuvos Tarybai veikti. Minsko lietuviai pageidavo, kad Lietuvos Taryba „tuojau imtų i savo rankas tremtinių Lietuvon grąžinimą ir tam tikslui išgautų iš vokiečių valdžios reikalingas lèšas" ${ }^{\text {"53 }}$.

$1918 \mathrm{~m}$. balandžio ménesị ị Vilnių atvyko net dvi VLTR delegacijos. Viena iš Voronežo, vadovaujama L. Noreikos, o kita iš Petrogrado, vadovaujama dr. Jurgio Aleknos ${ }^{54} .1918$ m. gegužès 8 d. abi delegacijas iškilmingai priėmė Lietuvos Tarybos prezidiumas. Šių delegacijų vadovai pripažino Lietuvos Tarybą , aukščiausiu ir vieninteliu mūsų tautos

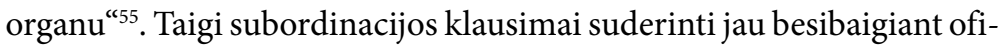
cialiai VLTR veiklai Rusijoje ${ }^{56}$. P. Čepeno teigimu, LVTR Voroneže oficialiai veikè iki 1918 m. balandžio 19 d., kiek ilgiau - LVTR padalinys Petrograde. Iš spaudos matyti, kad iš kalèjimo paleistas M. Sleževičius ir Z. Žemaitis, vos radęs galimybę, išvyko ị Maskvą, kad ten perkeltų LVTR centrą iš Voronežo ir pratęstų jo veiklą. VLTR ịsikūrè Maskvos lietuvių šelpimo draugijos būstinejje. Tačiau, vos paskelbus spaudoje, kad „Lietuvių Vyriausios Tarybos Rusijoje Centras persikèlè ị Maskvą“, ir pranešus apie tolesnị savo darbą ir adresą visuomenei, kitą dieną Vinco Kapsuko įsakymu buvo padaryta krata. Atliekant kratą Maskvos lietuvių šelpimo draugijos būstinèje, LVTR dokumentų nerasta ${ }^{57}$.

Kai kurie ị Lietuvą grịžę LVTR nariai buvo kooptuoti ị Lietuvos Tarybą, dalis jų, tarp jų ir kooptuoti į Lietuvos Tarybą, tapo jos igaliotiniais Rusijoje tremtinių ir pabėgèlių grąžinimo reikalais. Pavyzdžiui, 1918 m. balandžio 30 d. Lietuvos Taryba iggaliojo Teresę Prapuolenytę

${ }^{3} 19180409$ Minsko Lietuvių Tarybos posėdžio protokolas. LMAVB RS, f. 70-286, lap. 1.

${ }^{54}$ LVTR Petrogrado lietuvių delegaciją sudarè Jurgis Alekna, Jurgis Kubilius, Tadas Ivanauskas, Honorata Ivanauskienė, Aleksandras Žilinskas, Juozas Kerys, Antanas Jucevičius. Rusijos lietuvių delegacijų prièmimas. Vienybė. 1918, gegužès15 (Nr. 17), p. 257.

${ }^{55}$ Rusijos lietuvių delegacijų prièmimas. Vienybè. 1918, gegužè 15 (Nr. 17), p. 257.

${ }^{56}$ Čepènas, P. Naujuju laiku Lietuvos istorija. T. 2. Fotografuotas leidimas. Vilnius: Lituanus, 1992, p. 34-83.

${ }^{57}$ Žinios. Vadas. 1918, gegužès 5, p. 4. 
(VLTR Voroneže delegatę) pargabenti tremtinius moksleivius iš Voronežo, Tombovo, Jaroslavlio ị Lietuvą kartu su bendrabučio personalu ir visu lietuvių šelpimo organizacijų bei mokyklų turtu ir „atstovauti Lietuvos Tarybą šiais reikalais prieš Rusų, Vokiečių ir kitų valdžias" ${ }^{\text {"58 }}$. 1918 m. gegužès 8 d. Lietuvos Tarybos prezidiumas kartu su Tremtinių ir belaisvių grąžinimo komisija igaliojo kunigą dekaną Julijoną Jasienskį, Teresę Prapuolenytę, Jurgị Lynartą, kunigą Povilą Jakubėną pasiskolinti 50 tūkstančių markių, arba 35 tūkstančius 700 Rusijos rublių, šelpimo ir mokyklų ịstaigų iš Voronežo, Tombovo ir Jaroslavlio Lietuvon grąžinimo reikalais ir pasižadèjo tą pinigų sumą, jiems grị̌žus i Lietuvą, atiduoti ${ }^{59}$.

\section{Lietuvos Tarybos vyriausiasis igaliotinis Maskvoje 1918 m. gegužès 14 d. - rugpjūčio $21 \mathrm{~d}$.}

\subsection{Lietuvos Tarybos vyriausiojo igaliotinio Maskvoje paskyri-} mo kontekstas (1918 m. balandis-gegužè)

Brest Litovsko sutarties 10 paragrafe buvo numatyta užmegzti Vokietijos ir Sovietų Rusijos diplomatinius ir konsulinius santykius, sutarti ratifikavus. Sutartis Vokietijos Reichstage ratifikuota $1918 \mathrm{~m}$. kovo 22 d., vyriausybių ryšiai užmegzti $1918 \mathrm{~m}$. kovo antroje pusejje ${ }^{60}$. Diplomatinių santykių palaikyti ị Maskvą 1918 m. balandžio 18 d. išvyko Vokietijos pasiuntinys grafas Wilhelmas von Mirbachas-Harffas ${ }^{61}$. Sovietų Rusijos vyriausybẻ pasirūpino specialiu traukiniu nuo sienos

5819180430 Lietuvos Tarybos igaliojimas (nr. 135) Teresei Prapuolenytei. MAVB RS, f. 255-1096, lap. 3.

5919180508 Lietuvos Tarybos prezidiumo igaliojimas J. Jasenskiui, T. Prapuolenytei, J. Lynartui ir P. Jakubėnui. MAVB RS, f. 255-1096, lap. 4.

${ }^{60}$ Baumgart, W. Deutsche Ostpolitik 1918. Von Brest-Litowsk bis zum Ende des Ersten Weltkrieges. Wien u. München: Oldenbourg, 1966, S. 208. Prieiga per internetą: http://ubm.opus.hbz-nrw.de/volltexte/2010/2356/pdf/doc.pdf [Leidimas pakartotas 2010.]

61 Vokietijos pasiuntinys Maskvoje. Vienybe. 1918, Nr. 14, p. 213. 
iki Maskvos, skyrė patalpas ${ }^{62}$. Balandžio $24 \mathrm{~d}$. W. Mirbachas jau buvo Maskvoje. Sovietų Rusijos pasiuntinys Adolfas Abramovičius Joffè $\mathfrak{i}$ Berlyną atvyko $1918 \mathrm{~m}$. balandžio 20 dieną $^{63}$. Vokietijos generaliniai konsulatai Petrograde ir Maskvoje ịsteigti 1918 m. gegužès antroje pusèje $\mathrm{e}^{64}$.

Vokietijos kaizeris, pripažindamas Lietuvą de jure, pažadèjo teikti jai Vokietijos paramą ir globą valstybès kūrimo procese. Vokietijos užsienio reikalų ministerijos archyviniuose dokumentuose yra $1918 \mathrm{~m}$. balandžio 6 d. Vokietijos reicho ir Lietuvos Sąjungos sutarties projektas. Sutarties projekto 5 straipsnyje parašyta, kad Lietuva galès skirti savo diplomatinius ir konsulinius atstovus tik gavusi Vokietijos pritarimą („Litauen wird nur mit Eivernehmen mit dem Deutschen Reich diplomatische Vertreter empfangen und konsularische Vertreter su lassen" $)^{65}$. Buvo numatyta, kad Lietuva galès skirti diplomatinius atstovus tik kaimyninèse šalyse ir prie Šventojo Sosto. Tačiau jie turès veikti derindami savo veiksmus su Vokietijos atstovais tose šalyse ${ }^{66}$. Taigi, kaizeriui pripažinus Lietuvą, Vokietija perėmé diplomatinị ir konsulinị Lietuvos atstovavimą užsienyje. Lietuvos Tarybos paskirtas igaliotinis galëjo veikti tik kaip Vokietijos diplomatinès ar konsulinès tarnybos narys. Sutarties projekto nuostatai buvo taikomi praktikoje tais atvejais, kai Lietuvos Taryba pranešdavo Vokietijos karinei vadovybei apie ịvykusį faktą (užsienio šalyje paskirtą Lietuvos Tarybos igaliotinį, žr. 3.1.).

Lietuvos Tarybos vyriausiasis igaliotinis Rusijoje buvo paskirtas ne tiesiogiai, o per Vokietijos karinę vadovybę vienoje pusejje

62 Ten pat.

${ }^{63}$ Baumgart, W. Deutsche Ostpolitik 1918. Von Brest-Litowsk bis zum Ende des Ersten Weltkrieges. Wien u. München: Oldenbourg, 1966, S. 208. Prieiga per internetą: http://ubm.opus.hbz-nrw.de/volltexte/2010/2356/pdf/doc.pdf [Leidimas pakartotas 2010.]

${ }^{64}$ Ten pat, S. 210. Prieiga per internetą: http://ubm.opus.hbz-nrw.de/volltexte/2010/2356/ pdf/doc.pdf [Leidimas pakartotas 2010.]

65 Bundnisvertrag zwischen dem Deutschen Reich und Litauen. PAAA RZ201_021718_056-057.

66 Ten pat. 
(Lietuvoje) ir Vokietijos generalini konsulatą Maskvoje - kitoje (t. y. Sovietų Rusijoje). Tokiu pačiu keliu keliavo ir Lietuvos Tarybos vyriausiojo igaliotinio Maskvoje korespondencija (laiškai, dokumentai, pranešimai).

\subsection{Lietuvos Tarybos vyriausiojo igaliotinio Maskvoje „visai Ru- sijai“" paskyrimas ir problemos dèl igaliojimų vykdymo}

Lietuvos Tarybos vyriausiuoju igaliotiniu Sovietų Rusijoje buvo paskirtas inžinierius Česlovas Landsbergis. Pirmasis šią žinią 1918 m. balandžio 25 d. paskelbė „Darbo balsas“67 dar iki oficialaus igaliojimo išdavimo. 1918 m. gegužès 5 d. apie greitu laiku ị Maskvą atvyksiantị „nepriklausomos Lietuvos valstybès pasiuntinį“ paskelbė „Vadas“, perspausdindamas informaciją iš Rusijos laikraščių ${ }^{68}$. Lietuvos Tarybos igaliojimas lietuvių ir vokiečių (Vollmacht) kalbomis buvo parengtas 1918 m. gegužès 14 d. ${ }^{69}$, rusų (Удостовъреніе) kalba - gegužès 15 dieną ${ }^{70}$. Jame buvo parašyta, kad „Lietuvos Tarybos prezidiumas paveda Č. Landsbergiui rūpintis pabėgèlių ir iš Lietuvos ị Rusiją evakuotų institucijų grąžinimu i Lietuvą bei igalioja jị šiais reikalais veikti Lietuvos Tarybos vardu prieš rusų, vokiečių ir kitas valdžias." ${ }^{\text {"71 }}$ Šis paskyrimas sulaukė nemažai spaudos dėmesio. Apie Lietuvos Tarybos vyriausiojo igaliotinio paskyrimą rašè ne tik „Darbo balsas“, bet ir „Vienybë“ bei

${ }^{67}$ „Darbo balse“ buvo pranešta, kad Lietuvos Taryba paskyrė savo ịgaliotinị Rusijoje. Žr. Mūsų žinos. Vilnius. Darbo balsas. 1918, balandžio 25 (Nr. 18), p. 12; Mūsų žinios. Vilnius. Darbo balsas. 1918, birželio 6 (Nr. 24), p. 9.

68 „Rusų laikraščiai praneša, kad ūmu laiku ị Maskvą atvyks nepriklausomos Lietuvos valstybės pasiuntinys. Kai kurie laikraščiai rašo, kad pasiuntinys jau yra atvažiavęs ị Maskvą.“ Žinios. Vadas. 1918, gegužès 5, p. 4.

6919180514 Lietuvos Tarybos Prezidiumo igaliojimas Česlovui Landsbergiui (vokiečių kalba). Vollmacht. LMAVB RS, f. 255-1096, lap. 5.

7019180515 Lietuvos Tarybos Prezidiumo ịgaliojimas Česlovui Landsbergiui (rusų kalba). LMAVB RS, f. 255-1096, lap. 6.

7119180514 Lietuvos Tarybos Prezidiumo igaliojimas Česlovui Landsbergiui (vokiečių kalba). Vollmacht. LMAVB RS, f. 255-1096, lap. 5. 
Sibiro lietuvių leidinys „Pranešimas“ (Tomske) ${ }^{72}$. Lietuviai Rusijoje labai laukè Lietuvos Tarybos atstovo ir su jo atvykimu siejo viltis greitai grịžti ị tèvynę. Leidinyje „Vienybë“ paskirtojo vyriausiojo igaliotinio iggaliojimai buvo kiek „praplèsti“, ịtraukiant ị jo kompetencijos sritị oficialiame igaliojime nesančių dalykų („rūpintis visų Rusijos lietuvių šelpimu“) ${ }^{73}$.

Č. Landsbergio kandidatūrą Lietuvos Tarybos prezidiumui pasiūlè Lietuvos Tarybos tremtinių ir belaisvių grąžinimo komisija (vadovas Aleksandras Stulginskis). Prieš išvykdamas ị Maskvą (1918 m. gegužès 17 d.) vyriausiasis igaliotinis savo veiklos gaires suderino ir su Lietuvos Tarybos tremtinių ir belaisvių grąžinimo komisija, ir su Lietuvos Tarybos prezidiumu ${ }^{74}$. I Maskvą Č. Landsbergis atvyko 1918 m. birželio 4 dieną ${ }^{75}$. Vos atvykus paaiškejjo, kad Lietuvos Tarybos vyriausiasis igaliotinis negalès realizuoti visų jam duotų igaliojimų ir „veikti Lietuvos Tarybos vardu prieš rusų, vokiečių ir kitas valdžias" ${ }^{\text {"76 }} .1918 \mathrm{~m}$. birželio 5 d. Č. Landsbergis laiške Lietuvos Tarybai rašè, kad iš pokalbio su Vokietijos generaliniu konsulu paaiškejjo, jog jis savarankiškai negali išduoti („nes neturi teisès“) pasų ir apsaugos raštų (Schutzschein) Lietuvos piliečiams. Vokietijos generalinis konsulas reikalavo, kad Č. Landsbergis teiktų jam žmonių, norinčių vykti į Lietuvą ir gauti apsaugos raštus, prašymus, o Vokietijos konsulas išduotų jiems pasus

${ }^{72}$ CLBS žinojo apie „Lietuvos atstovo (посланник)“ atvykimą ị Maskvą $1918 \mathrm{~m}$. birželio $4 \mathrm{~d}$. ir labai džiaugèsi, kad jis rūpinsis „,visais lietuvių reikalais“. Žr. Centralis Lietuviu Biuras Sibire. Pranešimas No 2. Tomskas, 191807 15, p. 11.

73 Žinuteje buvo parašyta, kad Č. Landsbergis igaliotas „rūpintis visu Rusijos lietuviu šelpimu ir švietimo organizaciju, moksleiviu, tremtiniu - pabègèliu gražinimu Lietuvon ir tais reikalais atstovauti Lietuvos Taryba prieš rusus, vokiečius ir kitas valdžias". Žr. Lietuvos Tarybos igaliotiniai išvažiavo Rusijon. Vienybè. 1918, gegužès 29 (Nr. 19), p. 289.

${ }^{74}$ Lietuvos Tarybos iggaliotiniai išvažiavo Rusijon. Vienybè. 1918, gegužès 29 (Nr. 19), p. 289.

${ }^{75}$ CLBS žinojo apie „Lietuvos atstovo (посланник)“ atvykimą ị Maskvą $1918 \mathrm{~m}$. birželio $4 \mathrm{~d}$. ir labai džiaugèsi, kad jis rūpinsis „,visais lietuvių reikalais“. Žr. Centralis Lietuviu Biuras Sibire. Pranešimas No 2. Tomskas, 191807 15, p. 11.

${ }^{76} 19180514$ Lietuvos Tarybos Prezidiumo igaliojimas Česlovui Landsbergiui (vokiečių kalba). Vollmacht. LMAVB RS, f. 255-1096, lap. 5. 
ir apsaugos raštus Vokietijos valstybès vardu „kaip Lietuvos globėjas ir gynejjas“. Č. Landsbergis rašte Lietuvos Tarybai aiškino, kad jam duotus igaliojimus suprato taip: jis Lietuvos Tarybos atstovo vardu duoda pasus ir apsaugos raštus, o juos antspaudu patvirtina Vokietijos generalinis konsulas Maskvoje, kaip okupacinės valstybès atstovas. Č. Landsbergis prašè Lietuvos Tarybos nurodymų tuo klausimu ${ }^{77}$. Jo laišką Vokietijos karinè vadovybė Lietuvoje persiuntė Lietuvos Tarybai su prierašu, kad „Č. Landsbergis neturi teisès išduoti pasus ir apsaugos raštus" ${ }^{\text {"78 }}$.

Iš 1918 m. liepos 9 d. Lietuvos Valstybès Tarybos protokolo aiškèja, kad Č. Landsbergiui pradèti pabėgèlių ir turto grąžinimo darbų nepavyko, nes nebuvo susitarta su Vokietijos generaliniu konsulu Maskvoje dèl Lietuvos piliečių pasų išdavimo tvarkos. Vokiečiai reikalavo, kad pasus išduotų jie, o Č. Landsbergis tik vizuotų. Mūsų vyriausiasis ịgaliotinis su tuo nesutiko. Reikalavo, kad pasus išduotų jis, o Vokietijos generalinis konsulas tik vizuotų ${ }^{79}$. Nepavykus susitarti, kuriam laikui tremtinių grąžinimas iš Maskvos sustojo.

Kodèl taip nutiko? Kodèl Lietuvos Tarybos paskirtam atstovui (vyriausiajam igaliotiniui) Vokietijos generalinis konsulas Maskvoje neleido savarankiškai veikti? Ar tokie Vokietijos veiksmai, turint omenyje, kad 1918 m. kovo 23 d. kaizeris pripažino Lietuvą de jure ir visus Lietuvos pavaldinius isakyta oficialiuose dokumentuose vadinti Lietuvos piliečiais, buvo teisèti? O gal Č. Landsbergis nesuprato jam suteiktų igaliojimų?

Remiantis tuometine tarptautine konstitucine teise ir egzistuojančia tarptautine praktika, buvo nusistovejjusi tvarka, kad diplomatinị

7719180605 Lietuvos Tarybos vyriausiojo igaliotinio Rusijoje (Maskvoje) Č. Landsbergio laiškas Lietuvos Tarybai (Vilniuje). MAVB RS, f. 255-1096, lap. 11-11 apv.

7819180605 Vokietijos karo vadovybès Lietuvoje persiųstas Č. Landsbergio laiškas su prierašu (komentaru) Lietuvos Tarybai (Vilniuje). MAVB RS, f. 255-1096, lap. 10.

${ }^{79}$ Lietuvos Valstybès Tarybos protokolai, 1917-1918. Sudarè. A. Eidintas, R. Lopata. Vilnius: Mokslas, 1991, p. 252. 
atstovą galëjo skirti tik valstybė turinti vyriausybę ${ }^{80}$. Lietuva tuo metu, nors Vokietijos ir pripažinta de jure, nebuvo sudariusi vyriausybès, nes Vokietijos karinè vadovybė to padaryti neleido. Taigi jau vien dèl to Lietuvos Taryba diplomatinio atstovo skirti negalejo. Č. Landsbergis pagal jam suteiktus Lietuvos Tarybos prezidiumo igaliojimus buvo igaliotinis, kuriam pavesta eiti konsulines pareigas. Taigi akivaizdu, kad Č. Landsbergis savo igaliojimus tiksliai suprato. Tačiau reikia turèti omenyje tą faktą, kad Lietuva nebuvo Sovietų Rusijos pripažinta ir užmezgusi su ja diplomatinių santykių, o suvereno teises gavo iš Vokietijos $^{81}$, todèl realiai Č. Landsbergis Lietuvos Tarybos atstovavimą realizuoti galejo bendradarbiaudamas (t. y. per narystę) Vokietijos diplomatineje tarnyboje (taip, kaip ir Lietuvių draugijos igaliotiniai - per Rusijos diplomatinę tarnybą Pirmojo pasaulinio karo metais). Lietuvos Tarybos prezidiumas, skirdamas igaliotinius užsienio šalyse (naujai susikūrusiose), tokios subordinacijos visokiais būdais vengè. Analogiškai elgèsi ir lietuvių Tautinès Tarybos komitetai užsienio šalyse ${ }^{82}$.

Nors Č. Landsbergis ir buvo pavaldus Vokietijos generaliniam konsulatui Maskvoje, jis buvo vyriausiasis Lietuvos Tarybos igaliotinis Rusijoje, todèl kiti igaliotiniai (neturintys vyriausiojo igaliotinio statuso) turejo teikti informaciją ir su juo derinti savo veiklą. Vienas tokių igaliotinių buvo baronas Vilhelmas Egertas (Vasilijus Petrovičius). 1918 m. birželio 8 d. jis gavo Lietuvos Tarybos igaliojimą „važiuoti ị Rusiją tartis, vaduojantis duotąja <...> instrukcija, su žmonėmis, kurie galètų būti naudingi nepriklausomos Lietuvos valstybès atstatymui ir kurie norètų gauti Lietuvoje tarnybą“. Lietuvos Taryba pavedè baronui

${ }_{80}$ Jaščenka, A. Tarptautinès teisès kursas. T. 1, Konstitucinè tarptautinè teisè. Kaunas: VDU Teisių fakulteto leidinys, 1931, p. 132.

${ }^{81}$ Maksimaitis, M. Mažoji konstituanta: Lietuvos taryba atkuriant valstybinguma. Vilnius: Justitia, 2011, p. 113.

${ }^{82}$ Kaukazo lietuvių taryba ir jos veikla (20 metų sukakties proga). Lietuvos aidas. 1938, sausio 21; Kaukazo lietuvių taryba ir jos veikla (20 metų sukakties proga). Tęsinys. Lietuvos aidas. 1938, sausio 22; Kaukazo lietuvių taryba ir jos veikla (20 metų sukakties proga). Tęsinys. Lietuvos aidas. 1938, sausio 24. 
V. Egertui „pasirūpinti iš Rusijos vyriausybès palengvintų sąlygų savo reikalams baigti ir ị Lietuvą išvažiuoti tiems žmonèms, kurie panorètų Lietuvoje tarnauti“. Itvykdęs užduotị baronas turèjo grižti ị Lietuvą ${ }^{83}$. Bendraudamas su Rusijos vyriausybès ịstaigomis ir jų pareigūnais dèl „palengvinimų“ minètiems asmenims sutvarkyti savo reikalus Rusijoje ir išvykti ị Lietuvą, veiklą V. Egertas turejjo derinti su Č. Lansbergiu. Nurodytus asmenis, kuriems reikejo pagalbos, V. Egertas turèjo siųsti pas Č. Landsbergị, kad nekiltų kliūčių jiems išvykti ị Lietuvą ${ }^{84}$. Kitas, konkretų pavedimą turintis igaliotinis buvo Antanas Jucevičius. $1918 \mathrm{~m}$. liepos $4 \mathrm{~d}$. Lietuvos Tarybos prezidiumas igaliojo ji vykti i Rusiją ir ten rūpintis lietuvių geležinkelininkų grị̌zimu ị Lietuvą. Vokietijos ir Rusijos valdžių prašè padèti A. Jucevičiui vykdant jam pavestą užduotị ${ }^{85}$.

\subsection{Mykolo Sleževičiaus ir Konstantino Lapino bendradarbia-} vimas su Vokietijos generaliniu konsulu Maskvoje (1918 m. lieposrugpjūčio mèn.)

Susidariusią situaciją dèl Č. Landsbergio ir Vokietijos generalinio konsulo nesusikalbejjimo pasų išdavimo ir apsaugos raštų išdavimo reikalu bandè švelninti Lietuvių vyriausiosios tarybos Rusijoje vicepirmininkas M. Sleževičius ir Maskvos lietuvių šelpimo draugijos pirmininkas K. Lapinas. Situacija Maskvoje buvo ittempta, nes birželio

8319180608 Lietuvos Tarybos igaliojimas baronui Vilhelmui Egertui. MAVB RS, f. 255-1029, lap. 3. Jam išduotoje instrukcijoje buvo 4 punktai. Pirmame punkte buvo nurodyta, kad kalbantis su reikiamais žmonėmis reikia tureti omenyje, kad jie būtų lietuvių kilmės ir mokètų kalbėti lietuviškai. Antrame punkte pasakyta, kad apie visus sutikusius pereiti ị tarnybą Lietuvoje reikia pranešti Lietuvos Tarybos vyriausiajam igaliotiniui Rusijoje Česlovui Landsbergiui ir pateikti duomenis apie juos. Žr. 19180608 Lietuvos Tarybos instrukcija baronui Vilhelmui Egertui. MAVB RS, f. 255-1029, lap 1.

${ }^{84} 19180608$ Lietuvos Tarybos instrukcija baronui Vilhelmui Egertui. MAVB RS, f. $255-1029$, lap. 1.

8519180704 Lietuvos Tarybos prezidiumo ịgaliojimas (Vollmacht) Antanui Jucevičiui. LMAVB RS, f. 255-1096, lap. 9. 
pradžioje, nužudžius W. Mirbachą, buvo laukiama naujo Vokietijos pasiuntinio paskyrimo (Karlas Helfferichas buvo paskirtas $1918 \mathrm{~m}$. liepos $14 \mathrm{~d}$., atvyko liepos $28 \mathrm{~d}{ }^{86}$ ). Kaip tik tuo metu, $1918 \mathrm{~m}$. liepos 22 d., Lietuvos Taryba paskyrè inžinierių Aleksandrą Požèlą „Krašto atstovu Peterburge “87. Jo tarpininkavimu derybas dèl Lietuvos piliečių pasų ir liudijimų išdavimo tvarkos Maskvoje su Vokietijos generaliniu konsulu tęsė M. Sleževičius, LVTR vicepirmininkas, ir K. Lapinas, Maskvos lietuvių šelpimo draugijos pirmininkas.

M. Sleževičius ir K. Lapinas Vokietijos generaliniam konsului Maskvoje prisistatè kaip „asmenys paliudijimų patikrinimui“ (Vertrauenspersonen für Schutz-und Passierscheine) ${ }^{88}$ ir pasisiūlè veikti kartu išduodant liudijimus, kol Č. Landsbergis grịš ị Vilnių ir informuos Lietuvos Tarybą. Derybose buvo susitarta, kad Maskvos lietuvių šelpimo draugijos prašymai dèl liudijimų bus pateikiami K. Lapino ir M. Sleževičiaus gyvenamos vietos adresais. Maskvos lietuvių šelpimo draugijos pirmininkas turejo patikrinti pateiktus prašymus ir informuoti Vokietijos generalinị konsulatą Maskvoje, t. y. užpildyti „suomių komiteto Maskvoje“ naudojamą formuliarą. Prie užpildyto formuliaro turèjo būti pridedamas paliudijimas ir asmens tapatybę ịrodantys dokumentai. Už paliudijimo parengimą buvo imamas konsulinis mokestis ir išduodamas kvitas paliudijimo prašytojui ${ }^{89} .1918 \mathrm{~m}$. liepos-rugsèjo mènesiais paliudijimai buvo išduodami trimis kalbomis - lietuvių, vokiečių ir rusų ${ }^{90}$. Maskvos lietuvių šelpimo draugijos pirmininkas (K. Lapinas), remdamasis

${ }^{86}$ Baumgart, W. Deutsche Ostpolitik 1918. Von Brest-Litowsk bis zum Ende des Ersten Weltkrieges. Wien u. München: Oldenbourg, 1966, S. 233. Prieiga per internetą: http:// ubm.opus.hbz-nrw.de/volltexte/2010/2356/pdf/doc.pdf [Leidimas pakartotas 2010.]

8719180823 Lietuvos Tarybos viceprezidento raštas Vokietijos karinei vadovybei Lietuvoje dèl vyriausiujų atstovų Ukrainoje, Petrograde ir Tiflise paskyrimo. LMAVB RS, f. 255-1096, lap. 29.

${ }^{88} 1918$ metų (tikslesnès datos nèra; tikètina, liepos mèn.) dokumento, sudaryto su Vokietijos generaliniu konsulatu Maskvoje, nuorašas. LCVA, f. 1014, ap. 1, b. 31, lap. 2.

${ }^{89}$ Ten pat.

${ }^{90} 19180810$ paliudijimas Konstantinui Avižieniui. LCVA, f. 1561, ap. 1, b. 3, lap. 1. 
gautais dokumentais ir Vokietijos generalinio konsulato Maskvoje pranešimu, išduodavo paliudijimus, kad „LIETUVOS PILIETIS“ ittrauktas ì sąrašą asmenų, kurie yra Vokietijos generalinio konsulato Maskvoje globojami, ir kad „jis ir jo turtas yra ginami Vokiečių imperijos ir kad jis neturi būti šaukiamas Rusijos kariuomenèn "91 . Paliudijimas buvo išduodamas Maskvos lietuvių šelpimo draugijos pirmininko vardu, su jo parašu ir antspaudu ${ }^{92}$. Šių paliudijimų Lietuvos piliečiams pagrindu Vokietijos generalinis konsulatas išduodavo Lietuvos piliečio pasą ${ }^{93}$.

\section{Lietuvos Tarybos atstovai Maskvoje $1918 \mathrm{~m}$. rugpjūčio $21 \mathrm{~d}$. - lapkričio $11 \mathrm{~d}$.}

3.1. Lietuvos Tarybos atstovy Sovietu Rusijoje paskyrimo ir veikimo kontekstas $1918 \mathrm{~m}$. rugpjūčio-spalio mèn.

Lietuvos centriniame valstybès archyve Lietuvos Tarybos fondo 37 byloje yra išlikusi Tremtinių ir belaisvių grąžinimo komisijos struktūra ir veiklos planas, apimantis laikotarpi nuo $1918 \mathrm{~m}$. rugsèjo $1 \mathrm{~d}$. iki gruodžio 31 dienos. Dokumentas nedatuotas ir nepasirašytas. Plane buvo numatyti Tremtinių ir belaisvių grąžinimo komisijos skyriai, turintys atstovybes Vokietijoje ir prie Vokietijos ịstaigu Rusijoje, Ukrainoje, Suomijoje, užimtose Šiaurès srityse ir Pietų srityse ${ }^{94}$. Tremtiniams ir belaisviams grąžinti iš Rusijos buvo suplanuota skirti iš Lietuvos 8 asmenis ir 3 vietos lietuvius darbui atstovybeje (žr. 1 lentelę). Numatyta samdyti 3 tarnus ir 3 kurjerius ${ }^{95}$.

911918 metų (tikslesnès datos nèra; tikètina, liepos mèn.) dokumento, sudaryto su Vokietijos generaliniu konsulatu Maskvoje, nuorašas. LCVA, f. 1014, ap. 1, b. 31, lap. 2.

9219180810 paliudijimas Konstantinui Avižieniui. LCVA, f. 1561, ap. 1, b. 3, lap. 1.

931918 metų (tikslesnès datos nèra; tikètina, liepos mèn.) dokumento, sudaryto su Vokietijos generaliniu konsulatu Maskvoje, nuorašas. LCVA, f. 1014, ap. 1, b. 31, lap. 2.

94 LCVA, f. 1014, ap. 1, b. 37, lap. 2, 2a, 3.

95 Ten pat. 
1 lentele. Tremtinių ir belaisvių grąžinimo komisijos Rusijoje sąmata 1918 m. rugsèjo 1 d. - gruodžio 31 d.

\begin{tabular}{|c|c|c|c|}
\hline Skyrius / padalinys užsienyje & $\begin{array}{c}\text { Atlygis } \\
\text { už } 1 \text { mèn. } \\
1 \text { asmeniui } \\
\text { Vokietijos } \\
\text { markèmis }\end{array}$ & $\begin{array}{c}\text { Atlygis už } \\
4 \text { mėn. visam } \\
\text { personalui } \\
\text { Vokietijos } \\
\text { markèmis }\end{array}$ & Pastabos \\
\hline \multicolumn{4}{|c|}{ IV. Komisijos atstovybė Rusijoje } \\
\hline Vyriausiasis atstovas & 2500 & 10000 & \\
\hline 3 (trys) komisijos nariai & 1800 & 21600 & $\begin{array}{l}\text { Skaičiuotas atlygis } \\
3 \text { tarnautojams }\end{array}$ \\
\hline 4 (keturi) sekretoriai & 900 & 14400 & $\begin{array}{l}\text { Skaičiuotas atlygis } \\
4 \text { tarnautojams }\end{array}$ \\
\hline $\begin{array}{l}\text { Avansas pasirengti kelio- } \\
\text { nei ir išlaidos } 3 \text { atstovybès } \\
\text { asmenims }\end{array}$ & 800 & 2400 & \\
\hline $\begin{array}{l}\text { Komisijos narių kelionès } \\
\text { išlaidos }\end{array}$ & 1000 & 4000 & \\
\hline $\begin{array}{l}\text { Transporto išlaidos } \\
\text { (pabėgèlių pargabenimo) }\end{array}$ & & 154602,40 & \\
\hline Kanceliarijos biuro nuoma & 1000 & 4000 & \\
\hline Biuro poreikių išlaidoms & 500 & 2000 & \\
\hline $\begin{array}{l}3 \text { (trys) vietiniai komisijos } \\
\text { atstovai }\end{array}$ & 1500 & 18000 & $\begin{array}{l}\text { Skaičiuotas atlygis } \\
3 \text { tarnautojams }\end{array}$ \\
\hline $\begin{array}{l}\text { Kanceliarijos išlaidoms } \\
\text { kiekvienam komisijos } \\
\text { atstovui }\end{array}$ & 500 & 6000 & $\begin{array}{l}\text { Skaičiuotas atlygis } \\
3 \text { tarnautojams }\end{array}$ \\
\hline 3 (trys) tarnai & 400 & 4800 & $\begin{array}{l}\text { Skaičiuotas atlygis } \\
3 \text { tarnautojams }\end{array}$ \\
\hline 3 kurjeriai & 400 & 4800 & $\begin{array}{l}\text { Skaičiuotas atlygis } \\
3 \text { tarnautojams }\end{array}$ \\
\hline Nenumatytoms išlaidoms & 3000 & 12000 & \\
\hline
\end{tabular}

Sudaryta autores remiantis LCVA, f. 1014, ap. 1, b. 37, lap. 2, $2 a, 3$. 
1918 m. rugpjūčio 19 d. Vokietijos karinè vadovybè Lietuvoje kreipèsi $\mathfrak{i}$ Lietuvos Tarybą prašydama paskirti savo atstovą $\mathfrak{i}$ komisiją Maskvoje ir Kijeve ${ }^{96}$. Tikètina, kad šis Vokietijos karinès vadovybės kreipimasis susijęs su jau anksčiau minètu dokumentu. Vyriausiuoju Lietuvos Tarybos igaliotiniu Šiaurès srityse (Šiaurès frontui nuo Pskovo iki Oršos) 1918 m. rugpjūčio $20 \mathrm{~d}$. buvo paskirtas dr. Jonas Puodžiūnas. Vietinis iggaliotinis Oršoje turèjo būti jam pavaldus ${ }^{97} .1918 \mathrm{~m}$. rugpjūčio $21 \mathrm{~d}$. Lietuvos Valstybès Tarybos prezidiumas informavo Vokietijos karinę vadovybę (Lietuvoje), kad Lietuvos Tarybos vyriausiasis krašto atstovas Maskvoje (General-Landesvertreter in Moskau) yra inžinierius Tadas Šulcas (Thaddäus von Schultz). Jo atstovybès nariai yra advokatas Augustinas Janulaitis ${ }^{98}$, gimnazijos vyr. mokytojas (matematikos) Liudas Daukša ${ }^{99}$.

1918 m. rugpjūčio 23 d. Lietuvos Taryba informavo Vokietijos karinę vadovybę Lietuvoje, kad atsakydama ị vadovybès 1918 m. rugpjūčio $19 \mathrm{~d}$. raštą praneša apie vyriausiojo krašto atstovo (General-Landesvertreter) Ukrainoje inžinieriaus Juozo Jankevičiaus paskyrimą dirbti Kijeve (Didžioji Žitomiro g. 10) nuo 1918 m. liepos 22 dienos. Apie kitų jo dviejų bendradarbių paskyrimą atstovybeje pažadèta pranešti artimiausiomis dienomis. Kartu informuota, kad krašto atstovu Petrograde $1918 \mathrm{~m}$. liepos $22 \mathrm{~d}$. paskirtas inžinierius A. Požèla (adresas

9619180819 Vokietijos karo vadovybès raštas Lietuvos Tarybai. LMAVB RS, f. 2551096, lap. 27.

9719180820 Lietuvos Valstybès Tarybos Prezidiumo liudijimas Jonui Puodžiūnui. LMAVB RS, f. 255-1096, lap. 25.

981918 m. gegužès 21 d. Augustinas Janulaitis laiške Lietuvos Tarybai patarè pasirūpinti iš Lietuvos išvežtais archyvais, kad jie neatitektų Lenkijai, jis labai intensyviai tuo rūpinasi. Pasiūlè Lietuvos Tarybai deleguoti asmenị, kuris išsiaiškintų, kokie yra archyvai, ir apsaugotų juos nuo užgrobimo. Žr. 19180521 A. Janulaičio laiškas Lietuvos Tarybai. LMAVB RS, f. 255-1024, lap. 1.

9919180821 Lietuvos Tarybos Prezidiumo raštas Vokietijos karo vadovybei Lietuvoje. LMAVB RS, f. 255-1096, lap. 28. 
Moika 77-4), o Transkaukaze - 1918 m. liepos 23 d. - vyr. mokytojas Pranas Dailidè Tiflise (adresas Kirotschnaja 45) ${ }^{100}$.

1918 m. rugsèjo $5 \mathrm{~d}$. Vokietijos karinè vadovybė Lietuvoje kreipèsi i J. Šauli norėdama i Vokietijos generalinio konsulato Petrograde darbą ịtraukti kai kuriuos lietuvius. Atsiųstame jų sąraše buvo nurodyti Petras Maikauskas, Stanislovas Digrys, Andrius Dubinskis, chemikas Šadeikis, Aleksandras Požèla (Pozello $)^{101}$. J. Šaulys 1918 m. rugsėjo 6 d. atsakè, kad laiške išvardyti asmenys Lietuvos Tarybai yra gerai žinomi ir tikisi, kad jie dirbs prie lietuvių pabėgèlių i Lietuvą grị̌imo ${ }^{102}$.

Žvelgiant ị paskyrimo datas akivaizdu, kad Lietuvos Tarybos „krašto atstovai“ buvo paskirti anksčiau, nei to pareikalavo Vokietijos kariné vadovybè. Iš tiesų J. Jankevičius „atstovauti Lietuvos Tarybą prieš Ukrainos valdžią“ buvo paskirtas dar $1918 \mathrm{~m}$. birželio 7 dieną ${ }^{103}$. Tą pačią dieną išduotas specialus liudijimas ir M. Yčui pargabenti ligoninę ir jos personalą iš Besarabijos ${ }^{104}$.

Situacija, kai Vokietija neleido Lietuvos Tarybai skirti atstovų (vyriausiųjų ịgaliotinių, iggaliotinių, „krašto atstovų“) užsienyje, aiškindama, kad „atstovybių užsieniuose steigti Taryba neturinti teisès“, o Lietuvos

${ }^{100} 19180823$ Lietuvos Tarybos viceprezidento raštas Vokietijos karinei vadovybei Lietuvoje dèl vyriausiujų atstovų Ukrainoje, Petrograde ir Tiflise paskyrimo. LMAVB RS, f. 255-1096, lap. 29.

${ }^{101} 19180905$ Vokietijos karo vadovybès (Lietuvoje) raštas Lietuvos Tarybai (viceprezidentui J. Šauliui). LMAVB RS, f. 255-1052, lap. 1-1 apv.

10219180906 Lietuvos Tarybos Prezidiumo raštas Vokietijos karo vadovybei (Lietuvoje). LMAVB RS, f. 255-1052, lap. 2. Lietuvos Taryba 1918 m. spalio 28 d. informavo A. Požèlą, kad Petras Maikauskas suimtas Torošine. Tarybos vicepirmininkas buvo susirūpinęs Lietuvos atstovo laikomais pinigais. Siūlè laikyti kitos valstybès pasiuntinybejje. Arba kuo greičiau pargabenti juos ị Lietuvą. Patarè siųsti tik tuo keliu, kuriuo tikrai bus saugiai pristatyti. Žr. 19181028 Lietuvos Tarybos viceprezidento raštas Lietuvos Valstybės Tarybos atstovui Petrapilyje A. Požèlai. LMAVB RS, f. 255-1068, lap. 3-3 apv.

${ }^{103} 19180607$ Lietuvos Tarybos prezidiumo igaliojimas (Vollmacht) Jankevičiui. LMAVB RS, f. 255-1096, lap. 17.

${ }^{104} 19180607$ Lietuvos Tarybos prezidiumo liudijimas (Certificat) Martynui Yčui. LMAVB RS, f. 255-1096, lap. 14. 
Taryba vis tiek juos skyrė (1918 m. birželio-rugpjūčio mėn.), verta išsamesnio pasiaiškinimo. Apie draudimus steigti Lietuvos Tarybos atstovybes užsienyje atsiminimuose kalba Aleksandras Stulginskis ${ }^{105}$. Analogiška informacija yra ir 1918 m. spalio $1 \mathrm{~d}$. „Bègamosiose Lietuvos Valstybės Tarybos žiniose“, kad „Krašto atstovavimas užsienyje taip pat nepriderąs Lietuvos Tarybai ir todèl negalị būti leisti Tarybos atstovai ì Ukrainą, Petrapili ir Kaukazą. "106 Tačiau nẻ vienas Lietuvos Tarybos paskirtas atstovas (igaliotinis) užsienyje Vokietijos karinès vadovybės nebuvo atšauktas. Paskirtieji atstovai ne tik kad nebuvo atšaukti, bet Vokietijos karinè vadovybè, matydama, kad Lietuvos Taryba perspejjimo, jog „atstovybių užsieniuose steigti Taryba neturinti teisès“, nepaiso, rado būdą, kaip reaguoti ị susidariusią situaciją. Vokietijos kariné vadovybè, laikydamasi pirminès nuostatos, nepripažino sudarytos Lietuvos Tarybos atstovavimo užsienyje sąmatos, tačiau pasiūlè kitą būdą, kaip finansuoti jau paskirtų asmenų veiklą. Vokietijos karinė vadovybė paprašè nurodyti asmenis, kurie dirbtų prie šios vadovybès užsienyje tremtinių ir belaisvių grąžinimo reikalais, ir pasiūlè Lietuvos Tarybai „išrinkti Komisiją, kuri turètų ne vykdomąją, o patariamąją funkciją "107.

Taigi Lietuvos Tarybos paskirti „krašto atstovai“ Vokietijoje, Rusijoje, Ukrainoje, Suomijoje ir jų veikla buvo finansuojama iš tremtiniams ir belaisviams grąžinti skirtų pinigų, kurie buvo gaunami per Lietuvių draugiją nukentejusiems dèl karo šelpti (toliau - Lietuvių draugija). Vokietijos karinè vadovybė Lietuvoje $1918 \mathrm{~m}$. spalio $28 \mathrm{~d}$. informavo Lietuvos Tarybą, kad tam tikslui Lietuvių draugija laikotarpiui nuo 1918 m. rugsèjo 1 d. iki gruodžio 31 d. paprašè 352 tūkst. Vokietijos markių $^{108}$. Vokietijos karinè vadovybė Lietuvoje $1918 \mathrm{~m}$. spalio $31 \mathrm{~d}$.

${ }^{105}$ Stulginskis, A. Atsiminimai. Chicago: Pedagoginis lituanistikos institutas, 1980, p. 267-268.

${ }^{106} 19181001$ Bègamosios Lietuvos Valstybès Tarybos žinios. Nr. 4. LMAVB RS, f. 255-1063, lap. 7.

${ }^{107}$ Ten pat.

${ }^{108} 19181028$ Vokietijos karo vadovybès Lietuvoje raštas Lietuvos Tarybai. LMAVB RS, f. 255-1079, lap. 3. 
pranešè, kad buvo skirta 300 tūkst. Vokietijos markių ${ }^{109}$. Pinigų šiam tikslui buvo surenkama ir už paliudijimus. Mokestis buvo imamas tik iš pasiturinčių asmenų ${ }^{110}$.

\subsection{Lietuvos valstybės atstovo Maskvoje Konstantino Lapino ir jo bendradarbių veikla $1918 \mathrm{~m}$. spalio-lapkričio mẻn.}

1918 m. spalio 14 d. Lietuvos Valstybès Taryba igaliojo nuo $1918 \mathrm{~m}$. liepos ménesio kartu su Vokietijos generaliniu konsulu bendradarbiaujantị K. Lapiną būti atstovu ir ginti Lietuvos valstybès ir Lietuvos piliečių interesus Maskvos mieste ir jos apylinkèse „prieš Rusijos respublikos valdžią, o taip pat Vokietijos Reicho atstovybeje ir konsulate ir kitų valstybių atstovų tarpe "111. Nuo šios datos yra skaičiuojama nors ir trumpai veikusios Lietuvos Tarybos igaliotinio Maskvos atstovybès istorija.

1918 m. spalio-lapkričio mèn. Lietuvos piliečiams paliudijimai buvo išduodami dviem - lietuvių ir vokiečių - kalbomis. Paliudijimas buvo išduodamas Lietuvos Tarybos igaliotinio Maskvos atstovybès (Bevollmächtiger des Litauisches Staatsrates Moskauer Vertretung) ${ }^{112}$. Paliudijimo tekstas: „Lietuvos Tarybos igaliotinis šiuo liudija, kad šito apsaugos lapo savininkas yra tas pat asmuo, kurio fotografija aukščiau patalpinta ir kad po fotografija jo paties pasirašyta." ${ }^{113}$ Paliudijimas buvo adresuotas Vokietijos generaliniam konsulatui Maskvoje (An das Keiserlich Deutsche Generalkonsulat in Moskau) ${ }^{114}$. Lietuvos Tarybos igaliotinio Maskvos atstovybei likdavo užpildytas žinių apie

${ }^{109} 19181031$ Vokietijos karo vadovybès Lietuvoje raštas Lietuvos Tarybai. LMAVB RS, f. 255-1079, lap. 2.

${ }^{110}$ Lietuvos Valstybès Tarybos protokolai, 1917-1918. Sudarè A. Eidintas, R. Lopata. Vilnius: Mokslas, 1991, p. 399.

${ }^{111} 19181014$ LVT igaliojimas Konstantinui Lapinui (Maskvoje), rusų kalba. LCVA, f. 1014 , ap. 1, b. 38, lap. 4 .

${ }^{112}$ Liudviko Mankausko asmens byla. LCVA, f. 1014, ap. 1, b. 55, p. 1, 2, 3, 3 a.

${ }^{113}$ Ten pat.

${ }^{114}$ Ten pat. 
asmenị lapas, mokejjimo kvito išdavimo data ir numeris, pateiktų asmens tapatybę liudijančių dokumentų nuorašai, išduoto paliudijimo kopija ir protokolas. Protokole buvo įrašoma, $\mathrm{kad}$ „aš $<\ldots>$ laikau save LIETUVOS PILIEČIU, prašau mane imti savo globon ir išduoti man apsaugos lapą "115. $1918 \mathrm{~m}$. lapkričio mènesį dokumentus tvirtino jau ne Maskvos lietuvių šelpimo draugijos pirmininkas, o Lietuvos Tarybos igaliotinio Maskvos atstovybe $\dot{e}^{116}$.

1918 m. lapkričio 5 d. Vokietijai nutraukus su Sovietų Rusija diplomatinius santykius ${ }^{117}$ oficiali Lietuvos Tarybos igaliotinio Maskvos atstovybės veikla prie Vokietijos generalinio konsulato Maskvoje buvo sustabdyta. Tai matyti iš 1918 m. lapkričio 26 d. Lietuvos Valstybès Tarybos protokole esančios A. Stulginskio ataskaitos apie Tremtinių ir belaisvių komisijos darbą ${ }^{118}$. A. Stulginskis Lietuvos Valstybès Tarybai pranešè, kad „paskutiniu momentu tremtinių grąžinimas suiro" ${ }^{119}$. Iš Maskvos atstovybėje 1918 m. rugpjūčio-lapkričio mẻn. dirbusio Lietuvos Tarybos igaliotinio L. Daukšos interviu, pasirodžiusio spaudoje 1920 m. balandžio 7 d., aiškèja, kam buvo perduotas Lietuvos piliečių atstovavimas Maskvoje ir jos apylinkèse, Sovietų Rusijai nutraukus diplomatinius santykius su Vokietija. Jo teigimu, Lietuvos piliečių atstovavimas buvo pavestas Švedijos konsului. Šis rūpinosi Lietuvos piliečių dokumentais (pasais, metrikomis). Lietuvos Tarybos igaliotinio Maskvos atstovybės dokumentus perėmė Lietuvių reikalų komisariatas. Paimti dokumentai saugoti kartu su Lietuvos ūkio rūmų turtu' ${ }^{120}$.

${ }^{115}$ Liudviko Mankausko asmens byla. LCVA, f. 1014, ap. 1, b. 55, p. 3a.

${ }^{116} 19181106$ Lietuvos Tarybos igaliotinio Maskvos Atstovybės ị Vokietijos generalinị konsulatą Maskvoje. LCVA, f. 1014, ap. 1, b. 55, lap. 1.

${ }^{117}$ Baumgart, W. Deutsche Ostpolitik 1918. Von Brest-Litowsk bis zum Ende des Ersten Weltkrieges. Wien u. München: Oldenbourg, 1966, S. 258. Prieiga per internetą: http://ubm.opus.hbz-nrw.de/volltexte/2010/2356/pdf/doc.pdf [Leidimas pakartotas 2010.]

${ }^{118}$ Lietuvos Valstybès Tarybos protokolai, 1917-1918. Sudarè A. Eidintas, R. Lopata. Vilnius: Mokslas, 1991, p. 398-399.

${ }^{119}$ Ten pat, p. 399.

${ }^{120}$ Iš buvusio Lietuvos valdžios iggaliotinio darbuotès Maskvoje. Laisve. 1920, balandžio 7. 
L. Daukša savo veiklą Maskvoje tęsè neoficialiai, jis teikè patarimus ir žinias apie Lietuvą tautiečiams ${ }^{121}$.

\section{Išvados}

1. Išanalizavus Lietuvos atsiskyrimo nuo Rusijos paskelbimų chronologiją (1917 m. gruodžio 25 d., 1918 m. sausio 6 ir 26 d.) ir geografiją (Lozana, Stokholmas, Vilnius) paaiškejjo, kad visi jie padaryti tuo metu, kai vyko Vokietijos ir Sovietų Rusijos derybos, ir jais siekta gauti Antantės šalių pripažinimą dar iki pasirašant Vokietijos ir Sovietų Rusijos taikos sutarti. Lietuvos pilietis randasi $1918 \mathrm{~m}$. kovo $23 \mathrm{~d}$., ratifikavus Brest Litovsko sutarti Vokietijos Reichstage, Lietuvos Tarybos delegacijai Vasario 16-osios aktą notifikavus Vokietijos vyriausybei ir Vokietijos kaizeriui suteikus Lietuvai pripažinimą de jure. Vyriausioji lietuvių taryba Rusijoje Lietuvos Tarybą oficialiai pripažino ir buvo jai subordinuota $1918 \mathrm{~m}$. gegužès $8 \mathrm{~d}$., nors atskiri VLTR nariai ar igaliotiniai Lietuvos Tarybos igaliojimus veikti Sovietų Rusijoje jos vardu buvo gavę ir anksčiau.

2. Lietuvos Tarybos vyriausiasis igaliotinis Maskvoje „visai Rusijai“ Č. Landsbergis buvo paskirtas Vokietijai užmezgus su Sovietų Rusija diplomatinius ir konsulinius santykius ir 1918 m. gegužès mèn. įsteigus generalinius konsulatus Maskvoje ir Petrograde. Lietuvos Tarybos vyriausiasis pasiuntinys buvo subordinuotas Vokietijos generaliniam konsului Maskvoje ir jam įteiktame igaliojime nurodytų funkcijų atlikti negalejjo, nes vyriausybès nesudariusi Lietuva neturejjo teisès skirti diplomatinio ar konsulinio atstovo užsienyje. Susitarę su Vokietijos generaliniu konsulu Maskvoje VLTR vicepirmininkas M. Sleževičius ir Maskvos lietuvių šelpimo draugijos pirmininkas K. Lapinas Lietuvos piliečiams išduodavo paliudijimus, kurių pagrindu Vokietijos generalinis konsulas išduodavo jiems Lietuvos piliečio pasą ir apsaugos raštą.

${ }^{121}$ Ten pat. 
Kiti Lietuvos Tarybos paskirti igaliotiniai Sovietų Rusijoje buvo subordinuoti Č. Landsbergiui.

3. Lietuvos Tarybai $1918 \mathrm{~m}$. vasarą paskyrus du vyriausiuosius krašto atstovus Sovietų Rusijoje - Petrograde (liepos 22 d.) ir Maskvoje (rugpjūčio $21 \mathrm{~d}$. ir spalio $14 \mathrm{~d}$.), kurių igaliojimai priklausè tik konkrečiai miesto ir jo apylinkių jurisdikcijai, Lietuvos Tarybos atstovavimas Sovietų Rusijoje buvo decentralizuotas. Paskirti vyriausieji igaliotiniai atstovavo nebe Lietuvos Tarybai, o savo kraštui, valstybei ir jos piliečiams. Tačiau jie ir toliau buvo subordinuoti Vokietijos generaliniams konsulatams Maskvoje ir Petrograde. Lietuvos Tarybos vyriausiųjų krašto atstovų bendradarbių paskyrimą ir atleidimą koordinavo Lietuvos Tarybos prezidiumas, tvirtino Vokietijos karinè vadovybė Lietuvoje. Vokietijai nutraukus diplomatinius santykius su Sovietų Rusija, Vokietijos ir Lietuvos piliečių atstovavimą perèmé Švedija.

\section{REPRESENTATION OF THE COUNCIL OF LITHUANIA IN SOVIET RUSSIA IN 1918}

\section{SANDRA GRIgARAVIČIŪtė}

\section{Summary}

Keywords: Council of Lithuania; representation; authorised representative; Soviet Russia; Germany.

The article addresses the problems relating to the specificity of appointment, competence and activities of the chief authorised representatives of the Council of Lithuania in Soviet Russia (Moscow and Petrograd). The research covers the period from 14 May 1918 to 11 November 1918, i.e. from the appointment of Česlovas Landsbergis to the position of the chief au- thorised representative of the Council of Lithuania "for the whole Russia" in Moscow to the formation of the Lithuanian Provisional Government when Lithuania, which already had its own Government, could delegate its diplomatic representative abroad. The study reveals the actual mechanism of representation of the Council of Lithuania, Lithuania and Lithuanian 
citizens in the European part of Soviet Russia (up to the Urals) as part of the German diplomatic and consular service and shows the efforts to take over Lithuania's diplomatic and consular representation from Germany. The first part of the article analyses the origins of representation of the Council of Lithuania; it reveals when and where the separation from Russia was declared, when the citizen of Lithuania originated and how the process of subordination of the Supreme Lithuanian Council in Russia to the Council of Lithuania took place. The second part investigates the context of appointment and activities of Česlovas Landsbergis, the chief authorised representative of the Council of Lithuania in Moscow, his competence and the assistance of representatives of Lithuanian institutions in Russia in the fulfilment of the functions entrusted to him. The third part analyses the changes of representation of the Council of Lithuania in Soviet Russia from 21 August 1918 through 11 November 1918 and reveals how the competence and jurisdiction of chief authorised representatives evolved.

Iteikta 2017 m. rugsejjo $25 d$. 